\title{
Efficacy of Herbicides on the Yield of Lentil (Lens culinaris Medik.)
}

\author{
Shamima Aktar ${ }^{1 *}$, M. A. Hossain ${ }^{1}$, A. Siddika ${ }^{1}$, Nazmun Naher ${ }^{1}$ and M. R. Amin ${ }^{2}$ \\ ${ }^{1}$ Pulse Research Centre, ${ }^{2}$ On-Farm Research Division, Bangladesh Agricultural Research Institute \\ (BARI), Gazipur-1701, Bangladesh
}

*Corresponding author and Email: amin.bari@yahoo.com

Received: 13 August $2012 \quad$ Accepted: 18 May 2013

\begin{abstract}
A field experiment was conducted at Bangladesh Agricultural Research Institute, Gazipur during rabi (winter) season of 2008-09 to observe the efficacy of two herbicides on the yield of lentil (BARI masur-5). Paraxon, Whipsuper, Ronstar and Topstar were the herbicidal treatments applied after sowing of seeds and two leaf stage of weeds according to their mode of action. Dry weight of weed samples were recorded at 25 DAS and 40 DAS. The dry weight of weeds was found to be maximum in unweeded control. The highest yield of lentil $1086.6 \mathrm{~kg} \mathrm{ha}^{-1}$ was observed when Whipsuper was applied while the control treatment showed the lowest yield $\left(626.7 \mathrm{~kg} \mathrm{ha}^{-1}\right)$. A negative correlation existed between the weed dry matter weights and seed yield of lentil.
\end{abstract}

Keywords: Herbicide, efficacy, yield, lentil

\section{Introduction}

Lentil (Lens esculentus Medik.) is one of the important grain legumes in Bangladesh. It covers an area of 340,000 ha with annual production of 117,000 metric tons (BBS, 2007). However, the average yield of lentil is considerably low as compared to its potential yield of $1500-2000 \mathrm{~kg}$ $\mathrm{ha}^{-1}$, obtained in research field (BARI, 2010). Such lower yield may be attributed to the poor management of the crop among which poor weed management is an important one. Weed reduces yield through competition with crop plants for space, moisture, light and plant nutrients. Weeds exhaust soil depriving the crop of nutrients particularly nitrogen causing a considerable reduction in yield (Gautam and Singh, 1981). The yield reduction due to weed infestation can be prevented by keeping the weed's population density to minimum level.

There is a critical weed competition period for every crop when the weed causes maximum damage by competing with the crop plants (Nico et al., 1968). A very broad-based average period that is crucial for weeding in annual crops is the first 20-30 days after crop sowing or emergence (Gupta, 2003). The modern lentil varieties give good yield if the land remains weed free for the first one month. However, most of the farmers are reluctant to control weeds in lentil field timely and finally, looses yield. Inadequate weed control was found to reduce the yield $40-66 \%$ in lentil (Singh and Chowdhury, 1982; Singh and Singh, 1983). There are different ways of controlling weeds in the field among which the herbicidal control is gaining popularity among the farmers as the cost of labourers has been rising and the scope of mechanical control is not widening in Bangladesh. Herbicides inhibit the weed for considerable period after their application (Gupta, 2003). But data is meager regarding which herbicide is actually suitable for either pre-sowing or post-sowing application in lentil. It is therefore, imperative to find out the suitable herbicide(s) for controlling weeds in 
lentil by pre or post-sowing application without minimizing seed yield.

\section{Materials and Methods}

The field experiment was conducted at Central Research Farm of Bangladesh Agricultural Research Institute, Gazipur during rabi (winter) season of 2008-2009. The experiment was laid out in a Randomized Complete Block design with three replications. The trial consisted of four weedicides such as Paraxon (Paraquat dichloride), Whipsuper (9\% Phenoxaprop-PEthyl), Ronstar (40\% Oxadiazon) and Topstar (40\% Oxadiargyl) with one unweeded control (no herbicide and weeding) as treatments. The unit plot size was $5 \mathrm{~m} \times 4 \mathrm{~m}$. The seeds of BARI Masur-5 were sown at $30 \mathrm{~cm}$ apart in continuous seeding technique. Seeds were sown on 27 October, 2008 at a rate of $30 \mathrm{~kg} \mathrm{ha}^{-1}$.

The land was fertilized with 40-170-55 kg ha-1 of $\mathrm{N}-\mathrm{P}_{2} \mathrm{O}_{5}-\mathrm{K}_{2} \mathrm{O}$ in the form of urea, triple super phosphate and muriate of potash, respectively. All the fertilizers were applied as basal during the final land preparation. Paraxon $\left(1.5 \mathrm{ml} \mathrm{L}^{-1}\right.$ water), a non-selective herbicide was applied at moist condition of soil after sowing to control different grasses and broad-leaf weeds. Whipsuper (1.13 $\mathrm{ml} \mathrm{L}^{-1}$ water) was sprayed after emergence of two leaf stage of weeds, Ronstar ( $3 \mathrm{ml} \mathrm{L}^{-1}$ water) was sprayed immediately after sowing of seeds, Topstar $\left(1 \mathrm{ml} \mathrm{L}^{-1}\right.$ water $)$ was applied at moist condition of soil after sowing.

Two irrigations were applied, one at immediately after seed sowing and another at the vegetative stage (45 DAS) of crop. Intercultural operations such as mulching, thinning, applying insecticide were performed as and when required. Weed species grown at two leaf stage in each experimental plot were identified. Weed samples were taken at 25 and 40 days after sowing (DAS) from $1 \mathrm{~m}^{2}$ in each plot using quadrate and dry weights were recorded. The crop was harvested on 8 March, 2009. Yield components and seed yield of lentil were recorded and analyzed statistically by using MSTAT program. The treatment means were compared using LSD at $5 \%$ level of significance.

\section{Results and Discussion}

Different kinds of weeds grew in the experimental plots (Table 1), among which some were noxious such as bermuda grass (Cynodon dactylon), yellow nutsedge (Cyperus esculentus), and sensitive plant (Mimosa pudica). There were also some broad leaf weeds such as kanai nala (Cyanotis axillaris), kanai bashi (Commelina bengalensis) and water bind weed (Ipomoea aquatica). Vetch (Vicia sativa) was observed in the later stage of growth of lentil. Sweet et al. (1974) reported that there was a great variation in competition ability of crops plants with and associated plants. Reproduction of vegetative parts of some aquatic weeds was also observed in the experimental plots in the early rabi (winter) season.

Severe weed infestation was observed in the control plots both at 25 and 40 DAS (Fig.1 and Fig. 2). Herbicides reduced weed emergence according to their mode of action. At 25 DAS Whipsuper performed the best in controlling weed showing minimum dry weight of $60.79 \mathrm{~g}$ $\mathrm{m}^{-2}$ and $78.86 \mathrm{~g} \mathrm{~m}^{-2}$ when applied at 25 and 40 DAS, respectively and was followed by Ronstar $62.57 \mathrm{~g} \mathrm{~m}^{-2}$ and $88.48 \mathrm{~g} \mathrm{~m}^{-2}$ respectively. Weed dry matter accumulated by the application of Paraxon were $68.12 \mathrm{gm}^{-2}$ and $82.11 \mathrm{gm}^{-2}$ respectively. Topstar was found to be less effective and dry matter weight of weed was $98.27 \mathrm{~g} \mathrm{~m}^{-2}$ and $150.90 \mathrm{~g} \mathrm{~m}^{-2}$ respectively. Whipsuper seems to be better in controlling weeds in lentil. Weed dry matter is a better parameter to measure the competition than the weed number (Bhanumurthy and Subramanian, 1989). In the present study, unweeded control had significantly higher weed dry matter at all stages of crop growth due to unchecked growth of weeds.

Plant height, branch number plant ${ }^{-1}$ and 1000seed weight did not vary significantly due to the application of herbicides (Table 2). The highest 
plant population of lentil per $\mathrm{m}^{2}$ (103) was observed in the experimental plot where Whipsuper was applied. Plant population $\mathrm{m}^{-2}$ was statistically identical between Paraxon (93.67) and Topstar (93.00) treated plots. Plant population $\mathrm{m}^{-2}$ (78.00) was the lowest in control plots due to the severe weed infestation. Number of pods plant ${ }^{-1}$ was statistically similar in Whipsuper (42.87), Paraxon (39.20) and Ronstar (36.83) treated plots but the same was the lowest in Topstar (27.70). The data on lentil yields indicated significant differences due to treatments (Table 2).

Table 1. Weed species killed following the application of herbicides

\begin{tabular}{ll}
\hline Treatment & \multicolumn{1}{c}{ Weed species } \\
\hline Paraxon & $\begin{array}{l}\text { Bermuda grass (Cynodon dactylon), Barnyard grass (Echinochloa crussgalli), Joina } \\
\text { (Fimbrisrylis millacea), Grab grass (Elusine indica) }\end{array}$ \\
& $\begin{array}{l}\text { Bermuda grass (Cynodon dactylon), Barnyars grass (Echinochloa crussgalli), Knot } \\
\text { grass (Paspalum distichum), Vetch (Vicia sativa), Joina (Fimbrisrylis millacea), }\end{array}$ \\
& Grab grass (Elusine indica) \\
Ronstar & Yellow nutsedge (Cyperus esculentus), Vetch (Vicia sativa), Joina ( Fimbrisrylis \\
& millacea), Joina (Fimbrisrylis millacea), Knot grass (Paspalum distichum), \\
& Barnyars grass (Echinochloa crussgalli) \\
Topstar & Yellow nutsedge (Cyperus esculentus), Vetch (Vicia sativa), Joina ( Fimbrisrylis \\
& millacea), Joina (Fimbrisrylis millacea), Knot grass (Paspalum distichum), \\
& Barnyard grass (Echinochloa crussgalli) \\
& Bermuda grass (Cynodon dactylon), Grab grass (Elusine indica), Yellow nutsedge \\
Control & Cyperus esculentus), Joina (Fimbrisrylis millacea), Kanai nala (Cyanotis \\
& axillaris), Kanai bashi (Commelina benghalensis ), Keshur (Scirpus grossus), Knot \\
& grass (Paspalum distichum), Vetch (Vicia sativa), Pani Kachu (Monochoria \\
& vaginalis), Water bind weed (Ipomoea aquatica), Spine amaranth (Amaranthus \\
& spinosus), Sensitive plant (Mimosa pudica). \\
\hline
\end{tabular}

Table 2. Effect of herbicides on the yield contributing characters and yield of BARI Masur- 5

\begin{tabular}{|c|c|c|c|c|c|c|}
\hline Weedicide & $\begin{array}{c}\text { Plant } \\
\text { height } \\
(\mathrm{cm})\end{array}$ & $\begin{array}{c}\text { Plant } \mathrm{m}^{-2} \\
\text { (no.) }\end{array}$ & $\begin{array}{c}\text { Branch } \\
\text { plant }^{-1} \\
\text { (no.) }\end{array}$ & $\begin{array}{c}\text { Pod plant }^{-} \\
\text {(no.) }\end{array}$ & $\begin{array}{c}\text { 1000-seed } \\
\text { weight } \\
(\mathrm{g})\end{array}$ & $\begin{array}{l}\text { Seed yield } \\
\left(\mathrm{kg} \mathrm{ha}^{-1}\right)\end{array}$ \\
\hline Paraxon & 24.30 & 93.67 & 2.93 & 39.20 & 21.97 & $\begin{array}{l}906.20 \\
(144.59)\end{array}$ \\
\hline Whipsuper & 26.03 & 103.00 & 2.70 & 42.87 & 20.53 & $\begin{array}{l}1086.60 \\
(173.38)\end{array}$ \\
\hline Ronstar & 25.80 & 89.67 & 2.47 & 36.83 & 20.73 & $\begin{array}{l}799.80 \\
(127.62)\end{array}$ \\
\hline Topstar & 24.30 & 93.00 & 2.53 & 27.70 & 21.63 & $\begin{array}{l}900.00 \\
(143.60)\end{array}$ \\
\hline $\begin{array}{l}\text { Unweeded } \\
\text { control }\end{array}$ & 23.93 & 78.00 & 2.40 & 26.90 & 21.57 & 626.70 \\
\hline $\mathrm{LSD}_{0.05}$ & NS & 12.22 & NS & 7.75 & NS & 194.16 \\
\hline CV (\%) & 4.88 & 7.09 & 15.46 & 14.98 & 4.92 & 11.94 \\
\hline
\end{tabular}

Figures in parenthesis are percent of control values 


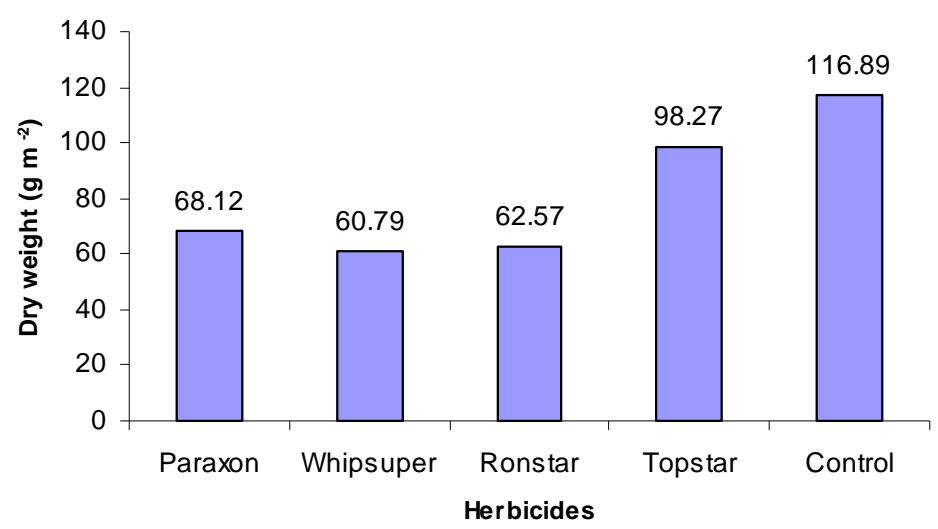

Fig.1. Dry matter accumulation by weeds at 25 DAS

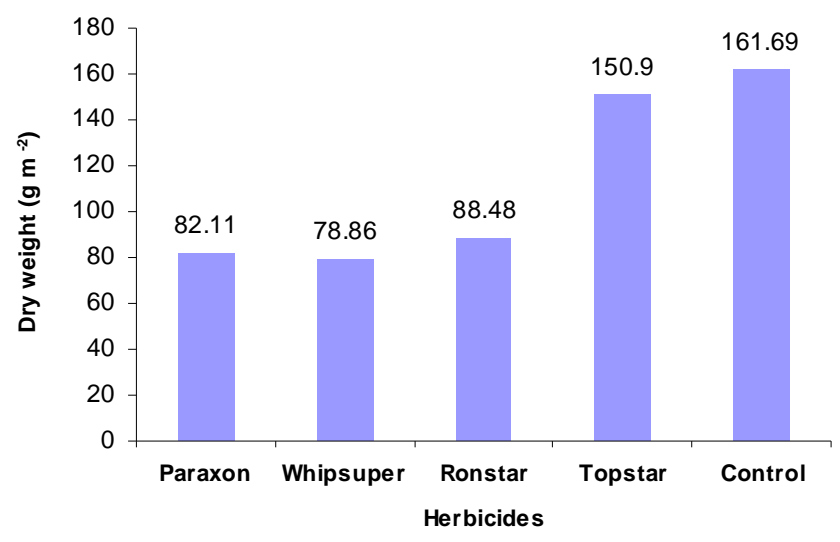

Fig.2. Dry matter accumulation by weeds at 40 DAS

Seed yield of lentil was the highest $(1086.6 \mathrm{~kg}$ $\mathrm{ha}^{-1}$ ) in Whipsuper which was statistically similar to with those of Paraxon (906.6 kg ha-1) and Topstar $\left(900.0 \mathrm{~kg} \quad \mathrm{ha}^{-1}\right)$. Herbicide application probably inhibited the growth of weeds facilitating proper growth of crop that ultimately led to the higher yield formations. Kassasian and Seeyave (1969) proposed that or successful crop production, crops required a weed free respite during the first $1 / 4$ or $1 / 3$ th of its growing season. Ronstar produced moderate yield (790.8 $\mathrm{kg} \mathrm{ha}^{-1}$ ) whereas, seed yield was the lowest $\left(626.7 \mathrm{~kg} \mathrm{ha}^{-1}\right)$ in unweeded control treatment. Klingman (1961) emphasized that the effect of weeds on growth and yield components ultimately determines the yield. The reduction may occur as a result of competition between the crop and weed for nutrients, space, light and water. Paraxon, Whipsuper, Ronster and Topstar showed 144.59, 173.38, 127.62 and $143.60 \%$ increased yields respectively over the unweeded control. Rao (1983) reported that losses from weeds accounts for 45 percent more than when compared to insect pests and diseases of about 
30 and 20 percent, respectively. In general, Whipsuper was more effective against different grasses. Ronstar and Topstar were effective against grasses, annual sedges and broadleaved weeds. Whipsuper performed better in controlling weeds than other herbicides.

The relationship between weed dry matter and seed yield of lentil is presented in figures 3 and 4. A negative correlation between weed dry matter weights $\left(\mathrm{g} \mathrm{m}^{-2}\right)$ and seed yield $\left(\mathrm{g} \mathrm{m}^{-2}\right)$ of lentil existed at both 25 DAS $(r=-0.70)$ and 40 DAS $(r=-0.65)$ indicated higher the weed dry matter the lesser was the yield. Weed dry matter weights accounted for $58 \%$ and $43 \%$ variations in yield at 25 and 40 DAS respectively, which might be due to the competition for growth resources between weeds and crop plants.

\section{Conclusions}

Weed infestation is one of the limiting factors in achieving optimum yield of lentil. The extent of yield reduction depends upon time, duration and intensity of weed infestation and weed competition with crops for growth resources. Application of herbicide can minimize weed infestation if the field can be kept weed free during the critical growth period. Application of Whipsuper seems to be better in controlling weeds in comparison with other herbicides.

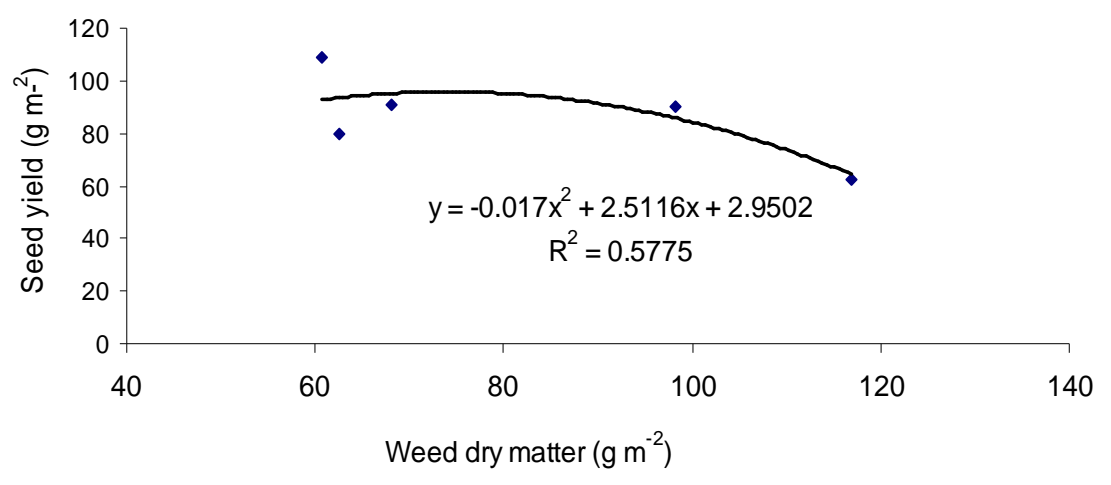

Fig. 3. Relationship between weed dry matter and yield of lentil at 25 DAS

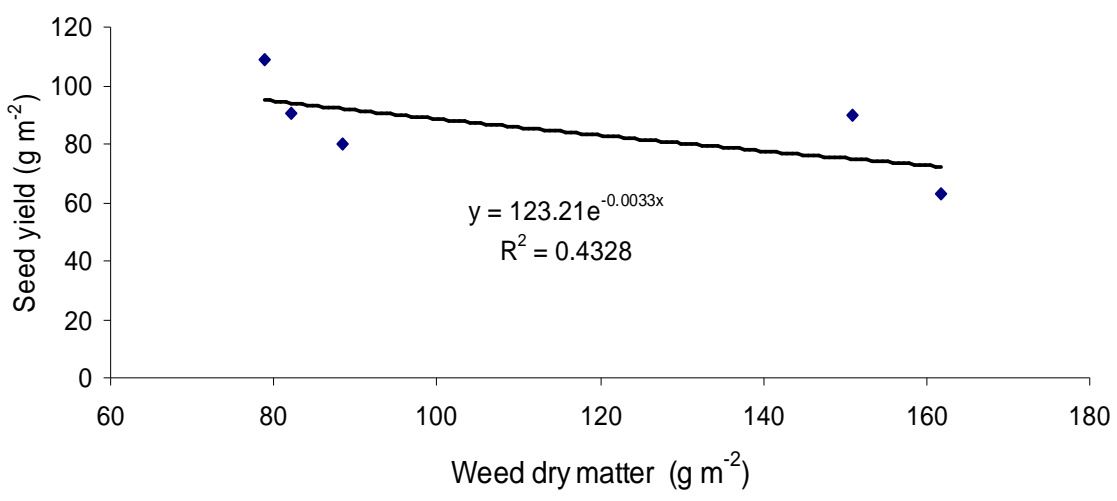

Fig. 4. Relationship between weed dry matter and yield of lentil at 40 DAS 


\section{References}

BARI (Bangladesh Agril.Res. Inst.). 2010. Annual Report of 2009-10. Bangladesh Agril.Res. Inst. Joydebpur, Gazipur-1701. 79-90 pp.

BBS (Bangladesh Bureau of statistics), 2007. Statistical yearbook of Bangladesh. Statistical Division, Ministry of planning. Government of the people's republic of Bangladesh. Dhaka. 126 p.

Bhanumurthy, V. B. and Subramanian, N. S. 1989. Adaptation of new parameters, grain yield competition for weed control study. Indian J. of Agril. Sci. 59:800-801.

Gautam, K. C. and Singh, M. 1981. Studies on economizing nitrogen fertilization in wheat through chemical weed control. Proc. Asia-Pacific Weed Sci. Conf. 11: 09-12.

Gupta, O. P. 2003. Weed management: Principles and practices. $2^{\text {nd }}$ edition. Agribios. India. pp. 11-24; 77-101.
Kassasian, L. and Seeyave, J. 1969. Critical periods for weed competition. PANS. 15:208- 212.

Klingman, G. C. 1961. Weed control Sci. John Willey and Sons. New York. 42 p.

Nico, J., Brabdo, M. L. and Gangaless, J. L. 1968. Critical period of crop growth cycle for competition from weeds. PANS (C). 14: 159-166.

Rao, V. S. 1983. Principles of Weed Sciences. Oxford and IBH publishing Co.Pvt.Ltd. 23-42 pp.

Singh, A. K and Singh, O. P. 1983. Effect of herbicides on yield and associated weeds in lentil. Indian J. Agron. 15(3): 228232.

Singh, R. and Chowdhury, S. L. 1982. A note on weed control in rabi pulses with preemergence and pre-planting herbicides. Indian J. Agron. 15(3): 302-304.

Sweet R. D., Yip, C. P. and Zieczka, J. B. 1974. Can crop control weeds. Infiletter Oregeon State University, USA. 20:36. 